National Bureau of Standardstererente Door hot is De

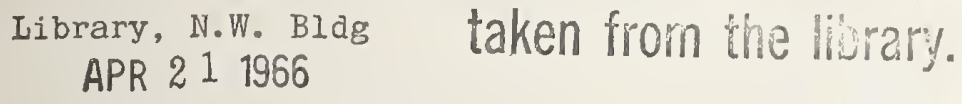

BUILDING SCIENCE SERIES 3

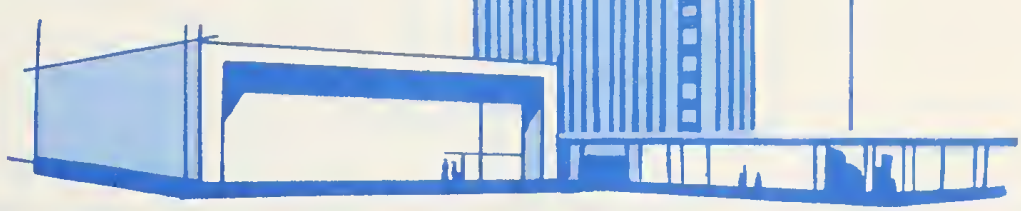

Doors

as Barriers

to Fire

and Smoke

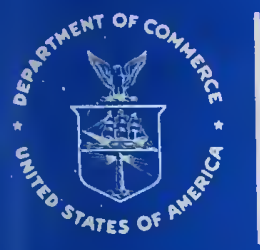

U.S. DEPARTMENT OF COMMERCE

National Bureau of Standards 


\section{Announcing - The Building Science Series}

The "Building Science Series" disseminates technical information developed at the Bureau on building materials, components, systems, and whole structures. The series presents research results, test methods, and performance criteria related to the structural and environmental functions and the durability and safety characteristics of building elements and systems.

These publications, similar in style and content to the NBS Building Materials and Structure Reports (1938-59), are directed toward the manufacturing, design, and construction segments of the building industry, standards organizations, officials responsible for building codes, and scientists and engineers concerned with the properties of building materials.

The material for this series originates principally in the Building Research Division of the NBS Institute for Applied Technology. Published or in preparation are:

BSS-1. Building Research at the National Bureau of Standards. (In preparation.)

* BSS-2. Interrelations Between Cement and Concrete Properties, Part I. 35 cents.

* BSS-3. Doors as Barriers to Fire and Smoke. 15 cents.

* BSS-4. Weather Resistance of Porcelain Enamels: Effect of Exposure Site and Other Variables After Seven Years. In press.

* The publications designated with an asterisk* are available by purchase from the Superintendent of Documents, Government Printing Office, Washington, D. C., 20402, at the prices indicated. See mailing list announcement on the last page. 


\title{
Doors as Barriers to Fire and Smoke
}

\author{
H. Shoub and D. Gross \\ Building Research Division \\ Institute for Applied Technology \\ National Bureau of Standards \\ Washington, D. C.
}

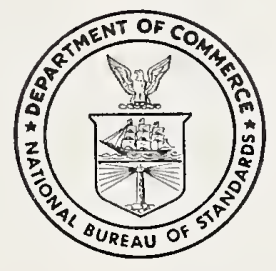

Building Science Series 3

Issued March 25, 1966

For sale by the Superintendent of Documents, U.S. Government Printing Office Washington, D.C. 20402 - Price 15 cents 


\section{Contents}

1. Introduction

2. Test method criteria

3. Test method and material $\ldots \ldots$

4. Results . .

5. Discussion $\ldots$

6. Summary

7. References _... 10 


\title{
Doors as Barriers to Fire and Smoke*
}

\author{
H. Shoub and D. Gross
}

\begin{abstract}
A study was made of means for improving dwelling unit entrance doors as fire and smoke barriers. Existing combustible doors and frames could be modified to enhance their firc resistance, but it did not appear practical to raise them to the level of rated commercial fire door assemblies. Fire retardant paints, exccpt those consisting of heavy, reinforced, intumescent-type coatings, provided little or no increase in fire resistance.

Several modifications of existing doors were not effective in preventing the transmission of smoke. However, controlling the pressure levels on both sides of a door, as by suitable venting, appeared to offer a means of reducing smoke penetration into an area.

It is recommended that current methods of fire tests of doors, and criteria relating to their fire and smoke transmission be improved.
\end{abstract}

\section{Introduction}

Entrance doors to individual dwelling units in multi-occupancy buildings, such as apartments or rooming houses, are generally recognized as weak fire-resistive elements in comparison with the partition walls into which they are built. In such housing, it has been common practice, especially in the past, to install an ordinary wood panel door in a wall that might otherwise provide several hours protection against fire originating in adjacent or remote areas of the building.

It was shown over 25 years ago that ordinary wood doors of the flush and paneled types, when exposed to standard fire tests, failed by allowing: passage of flames in $4 \frac{3}{4}$ to $8 \frac{1}{2} \mathrm{~min}$ [1]. ${ }^{1}$ It was appreciated that; other than the door and panel thickness, important test variables included the clearances between the door and the frame, the effects of warping, the type of hardware used, and the method of attachment.

To correct this deficiency, means are needed to enhance the fire safety of doorways and doors, particularly in older buildings, which, in some areas, are the target of retroactive ordinances enacted to require increased fire safety precautions.

Coequal with, or perhaps of even greater importance than the problem of fire penetration, is that of the transmission of smoke through and

*The paper will also be published as a contribution to the Proceedings of a Symposium on Methods and Application of Fire Testing, by the Armstroug Cork Company. The paper formed the basis of a presentation at the Symposium.

IFigures in brackets indicate the literature references at the end of this report. around the edges of the door. Aside from the possibly lethal effects of toxic decomposition products (more fire fatalities are caused by asphyxiation than by burns [2]) smoke introduces a serious handicap to human visibility. Such smoke usually originates from the burning contents of the building, but may be aggravated by fire attack on the door itself.

An obvious means of reducing the fire penetration hazard would be to replace the door and frame with a rated fire door assembly, i.e., one satisfying the requirements for a class $\mathrm{C}$ or better rating in the Standards of the National Board of Fire Underwriters [3]. Perhaps for economic considerations, this requirement has not been applied in all codes, especially in those provisions pertinent to existing buildings. In some jurisdictions, where the intent has been to increase the fire safety of existing doors, the codes have permitted this requirement to be met by the application of a coat of fire-retardant paint to the door structure, with no assurance that this would achieve the desired purpose.

In the series of tests described in this paper the effectiveness of fire-retardant paints was examined. In addition, this series included tests of old doors modified in various other ways designed to increase their utility as fire barriers. Several means for reducing the flow of smoke past the door were also examined. Finally, a study was made of the feasibility of controlling the movement of smoke and combustion products by the displacement of the neutral pressure zone in the test furnace chamber, as might be accomplished by the arrangement of suitable ventilating facilities. 


\section{Test Method Criteria}

The performance of a fire door assembly is commonly measured by the ability of the door to protect the opening in which it is installed against the passage of flame and heat. Door ratings are provided which are designed to agree with the following classifications $[3,4]$.

\begin{tabular}{|c|c|c|c|}
\hline Type of wall & Class & $\begin{array}{l}\text { Time } \\
\text { rating }\end{array}$ & $\begin{array}{l}\text { Temp. rise } \\
\text { limitations }\end{array}$ \\
\hline Fire (Building div.) & $\begin{array}{l}\mathrm{A} \\
\mathrm{A} \\
\mathrm{A}\end{array}$ & $\begin{array}{l}h r \\
3 \\
3 \\
3\end{array}$ & $\begin{array}{l}250^{\circ} \mathrm{F} \max , 30 \mathrm{~min} \\
650^{\circ} \mathrm{F} \max , 30 \mathrm{~min} \\
\text { None }\end{array}$ \\
\hline $\begin{array}{l}\text { Vertical communica- } \\
\text { tion enclosure }\end{array}$ & $\begin{array}{l}\mathrm{B} \\
\mathrm{B} \\
\mathrm{B} \\
\mathrm{B}\end{array}$ & $\begin{array}{l}1 \frac{1}{2} \\
1 \frac{1}{2} \\
1 \frac{1}{2} \\
1\end{array}$ & $\begin{array}{l}250^{\circ} \mathrm{F} \max , 30 \min \\
650^{\circ} \mathrm{F} \max , 30 \min \\
\text { None } \\
250^{\circ} \mathrm{F} \max , 30 \min \end{array}$ \\
\hline $\begin{array}{l}\text { Corridor and room } \\
\text { partition }\end{array}$ & $\mathrm{C}$ & $\frac{3}{4}$ & None \\
\hline $\begin{array}{l}\text { Exterior } \longrightarrow \text { severe } \\
\text { exposure hazard }\end{array}$ & $\begin{array}{l}\mathrm{D} \\
\mathrm{D} \\
\mathrm{D}\end{array}$ & $\begin{array}{l}1 \frac{1}{2} \\
1 \frac{1}{2} \\
1 \frac{1}{2}\end{array}$ & $\begin{array}{l}250^{\circ} \mathrm{F} \max , 30 \mathrm{~min} \\
650^{\circ} \mathrm{F} \max , 30 \mathrm{~min} \\
\text { None }\end{array}$ \\
\hline $\begin{array}{c}\text { Exterior-moderate } \\
\text { exposure hazard }\end{array}$ & $\mathrm{E}$ & $\frac{3}{4}$ & None \\
\hline
\end{tabular}

The establishment of limitations on unexposed surface temperatures in fire tests is based on the prevention of ignition of combustibles in close proximity to the test specimen. In the classification, the limiting temperature rise requirements are not mandatory, and when used, apply only to the first half hour. It would appear that a criterion based on the radiation flux at a specified time and at a given distance from a door would be more appropriate. Also, the standard test procedure $[4,5]$ bases acceptable performance of a fire door assembly on restricted movements and separations, with no clearly stated restrictions with regard to flame passage, and none for smoke. British [6] and other European standards require that the unexposed surface temperature shall not rise more than 250 $\operatorname{deg} \mathrm{F}$ throughout the entire test period for all classifications and no openings through which flame can pass shall develop in the assembly. The temperature rise requirement, however, may be waived for steel doors.

No standardized procedures exist with regard to the maintenance of a positive or negative furnace pressure or of pressure distribution during a test. The current test method $[4,5]$ requires that the pressure in the furnace chamber be maintained "as nearly equal to the atmospheric pressure as possible" without indicating the location at which the pressure measurement is to be made. Some laboratories have assumed the practice of operating with a low order negative pressure in the furnace chamber. This practice arises from the use of a mechanical draft, and probably accounts for recorded observations of no significant smoke passage during tests of painted metal doors, metal-clad wooden doors, or even ordinary wood doors. In vertical panel test furnances operating under natural draft conditions, significant pressure differences with respect to height exist within the furnace chamber.

\section{Test Method and Material}

The door assemblies were subjected to fire tests in the National Bureau of Standards' panel furnace, using a test frame arranged to permit fire test exposure of two door assemblies simultaneously. The door frame structures filled two openings, each approximately 4 - by 8 -ft, in the furnace test frame, with the door framing members covered with gypsum board and plaster, representing a wood stud wall construction. To simulate exposure of an apartment entrance door to a fire in the corridor, the doors were made to open outward away from the furnace. This exposed the stops but not the hinges. To preserve some measure of furnace closure when one of the door assemblies burned through while its companion specimen remained intact, the furnace test frame was provided with a pivoted shielding panel between the two door assemblies. This could be swung to either side so as to provide a flame barrier upon failure of one of the door assemblies.

The furnace temperatures were determined from 12 thermocouples mounted in iron pipes symmetrically distributed within the furnace chamber. All thermocouple leads were sheathed in insulating porcelain tubes before insertion into the pipes. Furnace temperature readings were recorded automatically each minute of the test duration.

The only criterion of failure used was of flame penetration to the unexposed surface or along the edges without regard to any temperature rise that, 
may have occurred during the test period. The test specimens were representative in size of the type of door employed for class $\mathrm{C}$ ratings and were tested in accordance with the requirements of ASTM E-152, except as noted. However, the hose stream test, specified to follow fire exposure, was omitted.

The principal features of the door assemblies tested are listed in table 1 , which also includes test results to facilitate comparisons.

With the exception of two commercial steel fire doors, the door assemblies consisted of used twin panel doors, nominally 34 by $80 \mathrm{in}$., $1 \frac{3}{8}$ in. thick with $\frac{3}{8}$ in. thick panels, removed from a razed apartment building and modified as noted.

To make a solid structure of an old panel door, the panel spaces were filled with $\frac{1}{2}$-in. plywood. Spaces at the panel edges, occupied by a decorative molding, were filled with a plaster-sawdust mixture to the height of the rails and stiles. The door was then faced with the appropriate covering material, $\frac{1}{8}$-in. hardboard or asbestos-cement board, or 24 gage galvanized steel sheet, attached with screws. Where sheet metal was used, a $\frac{3}{4}$ - by $\frac{1}{4}$-in. steel channel was applied to cover the metal edges. For "hollowflush" doors, hardboard coverings were applied directly, without filling the panel spaces.

The steel fire doors used in the tests were reported as meeting the requirements for class $\mathrm{B}$ or class $\mathrm{C}$ ratings. They were purchased complete with hardware and metal door frames. The thickness of each door was $1 \frac{3}{4}$ in.

Framing to support the doors was mostly of nominal 2- by 4-in. lumber, and was designed for mounting in the furnace test frame. The wooden trim of the door frame was covered with sheet metal in many of the tests (see table 1), and the faces of the trim, but not the edges, were sheathed with strips of 4 -in. wide asbestos-cement board. In the case of the commercial fire doors, the metal frames were attached to the wooden bucks of the built-up framing. Figure 1 shows a typical door used in the tests, and some details of the framing in which it was mounted.

Construction of the door assemblies and the appurtenent frames was in accordance with good practice, so that failure in the tests was assumed to result from the effects of fire rather than from structural deficiency.

Paint application was in accordance with the recommended coverage for the particular product, or, lacking instructions, the paint covering was the best possible that could be achieved with the
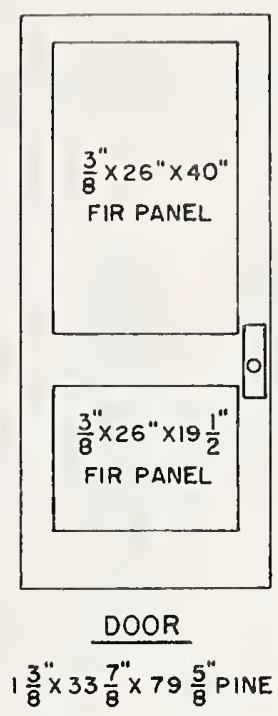
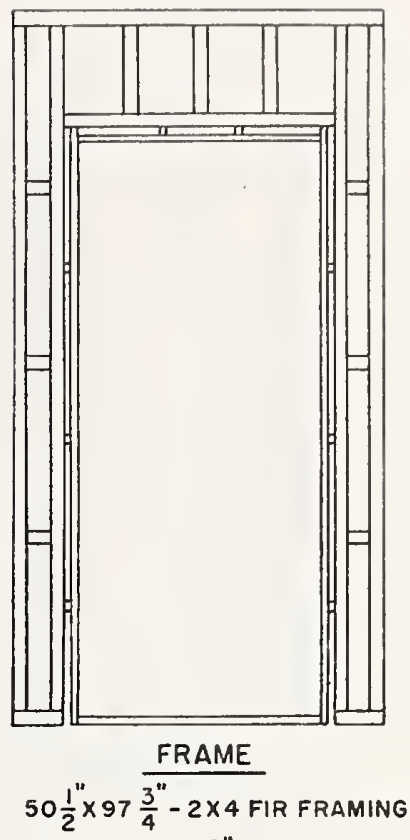

WITH $34^{\prime \prime} \times 79 \frac{3 "}{4}-1 \times 6$ PINE

DOOR OPENING
Figure 1. Typical door and frame construction.

materials, using either a brush or roller as appeared to be most suitable. Glass fiber reinforced paint, however, was usually applied by troweling to secure even coverage and a reasonably smooth surface finish. With this method, the spreading rate was about $60 \mathrm{ft}^{2} / \mathrm{gal}$.

Commercial weatherstripping, applied to the door frame in some tests, in an effort to reduce smoke passage, was of the friction type, and made of galvanized steel or $1 \frac{3}{8}$ in. wide spring bronze.

In an actual fire, smoke production may be considerable, arising as it does from complete or partial burning of the building contents and structure. In fire tests, the amount of smoke is usually limited to that produced by the door and frame assembly only, since the gas fuel used in the furnace provides practically no visible decomposition products. To make the tests more nearly representative of actual fire conditions, approximately 35 lineal feet of 2by 4 -in. white pine lumber (approx. $35 \mathrm{lb)}$ was mounted in the furnace in close proximity to the door frames to provide an additional source of smoke.

Because of the inadequacy of qualitative visual interpretations of smoke passage, quantitative measurements of the smoke issuing from above the door opening were made. Smoke measuring apparatus, shown schematically in figure 2, was mounted just above the top edge of each door, so 


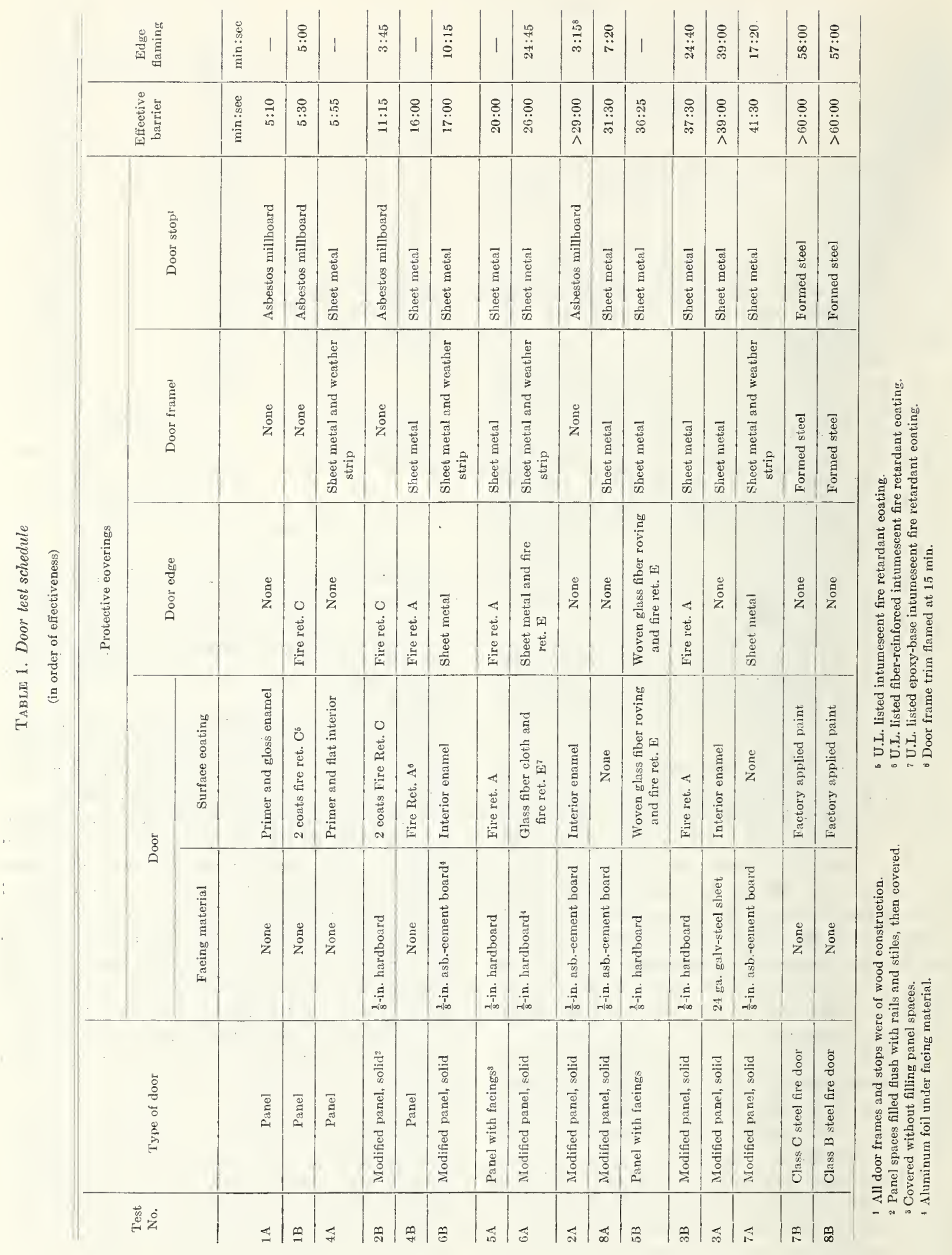




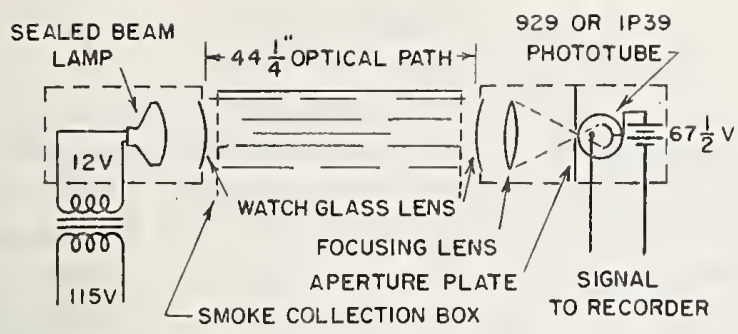

SCHEMATIC OF MEASURING SYSTEM

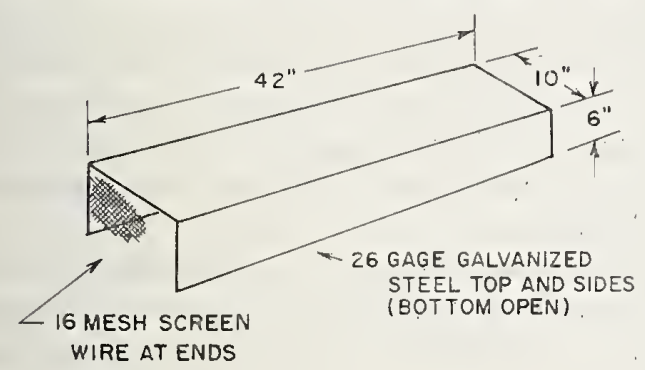

SMOKE COLLECTION BOX

FIGURE 2. Smoke measuring apparatus.

that smoke rising in front of a door was concentrated in the metal collection box where it obscured the light beam impinging on the vacuum phototube. A continuous recording was made of the output of the phototube, the response of which was essentially linear with respect to the transmission $(T)$ of light across the optical path between source and phototube. Since the transmission of light through a smoke aerosol appears to follow the Beer-Bouguer law, the proper measure of smoke concentration is the optical density, which is defined as $\log _{10} 1 / T$ and expressed per foot of optical path length.

Pressure measurements within the furnace were made by means of small static pressure probes and a differential pressure meter capable of detecting pressure difference of the order of 0.002 in. water. The "lollypop" probe consisted of $\frac{1}{8}$-in. i.d. stainless steel tubing attached to the edge of a $1 \frac{1}{8} \mathrm{in}$. diam flat metal disk having rounded edges and connected to a small hole in the center of the disk. The disk was positioned so that the hole was normal to the upward flow of gases. Except as adjusted and noted under Discussion, the existing pressure in the furnace (prior to fire penetration of a door assembly) provided positive pressures above that of the ambient atmosphere of approximately $0.10 \mathrm{in}$. water at the top and 0.02 in. water at the bottom edges of the door (see fig. 3).

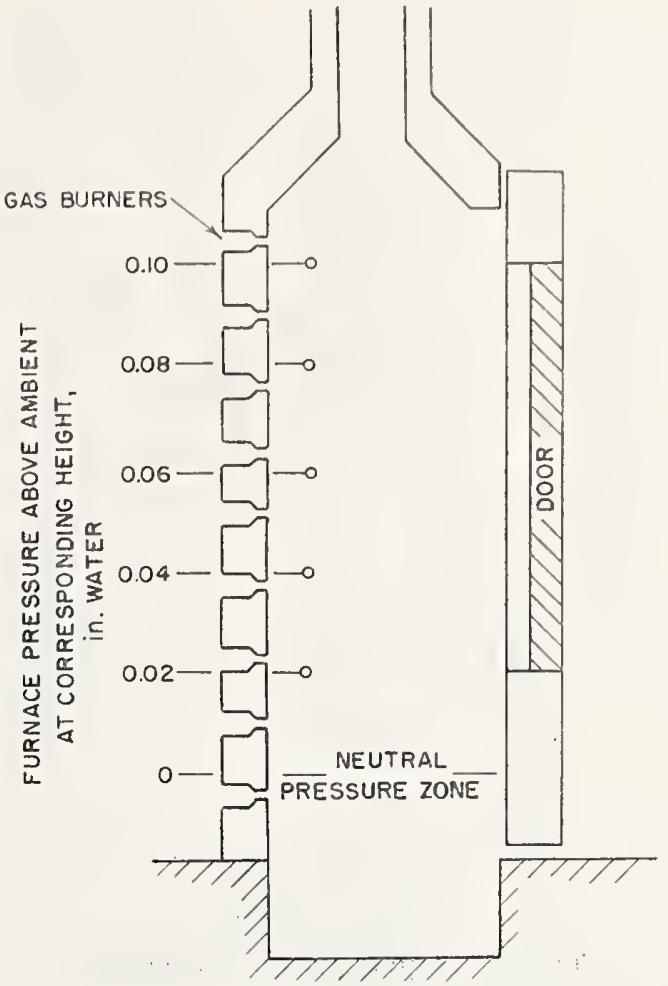

Figure 3. NBS panel test furnace: Schematic.

As dense smoke usually issued from around the doors, within 1 or $2 \mathrm{~min}$. from the start of a test, smoke measurements were possible in tests of even the shortest duration. Figure 4 shows typical curves of smoke density during the early stages of a test.

Figure 5 shows typical test curves of the furnace pressure at two elevations, and includes a derived curve of the location of the neutral pressure zone.

\section{Results}

Eight pairs of doors were tested and the results are listed in table 1 . The time durations shown under the "Effective Barrier" column indicate the period for which the door may be considered a barrier to the direct passage of flame through the door into the unexposed space. However, in many instances, it was noted that a minor amount of flaming occurred at the edges of a door, sometimes a considerable time before direct flame breakthrough. Where this phenomenon was sustained, the time of its first occurrence is shown in the column under "Edge Flaming." In those instances where the test was terminated before the passage of flame through a door, the duration is indicated as "greater than" the fire exposure time. 


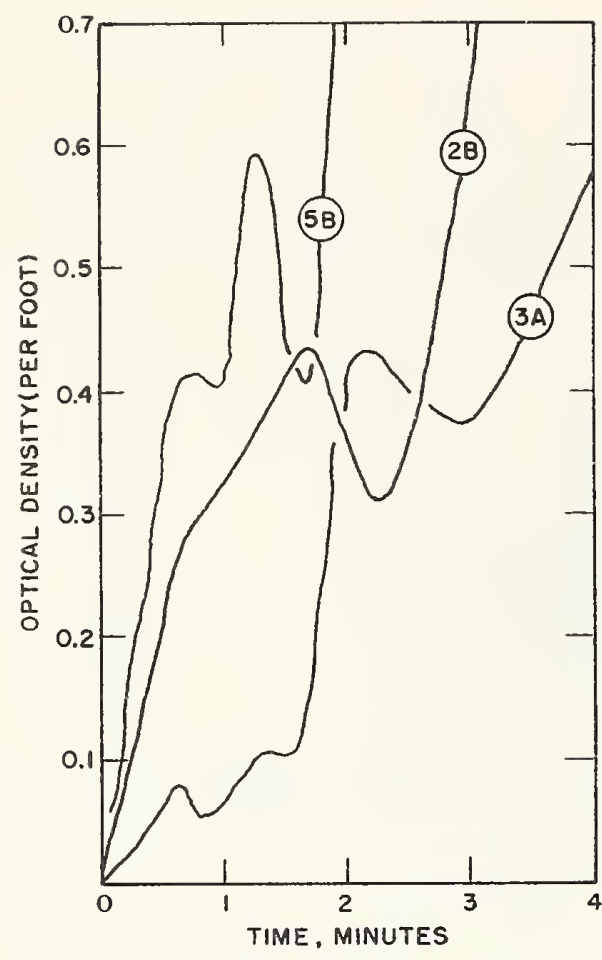

FIGURE T. Typical smoke measurements.

\section{Discussion}

A conventional wood panel door and frame assembly cannot be expected to act as an effective fire balrier for more than about $5 \mathrm{~min}$, under conditions of the standard fire test. From the results shown in table 1, the application of conventional paints (Tests $1 \mathrm{~A}$ and $4 \mathrm{~A}$ ) and a conventional commercial fire-retardant paint (Test 1B) do not provide any significantly greater protection. However, a panel door with a fire-retardant paint coating containing glass fiber reinforcement (paint A) acted as a fire barrier for $16 \mathrm{~min}$. In this test (4B), additional protective coverings were applied on the door edges and door frame, but such protection in itself did not appear to be effective in increasing the fire endurance.

The door assemblies with noncombustible facings of sheet steel and asbestos cement board, either filled-in or hollow flush, showed definite improvement in fire performance. The time durations during which these doors acted as effective barriers ranged from 17 to $41 \frac{1}{2}$ minutes. Of the hardboard-faced door assemblies, a filled-in door with the conventional

2B-Solid, hardboardf aced, fire-retardant C

3A-Solid, galv. steel sheet faced, interior enamel

5B-Panel faced with hardboard, glass fiber roving and fire-retardant $\mathrm{E}$
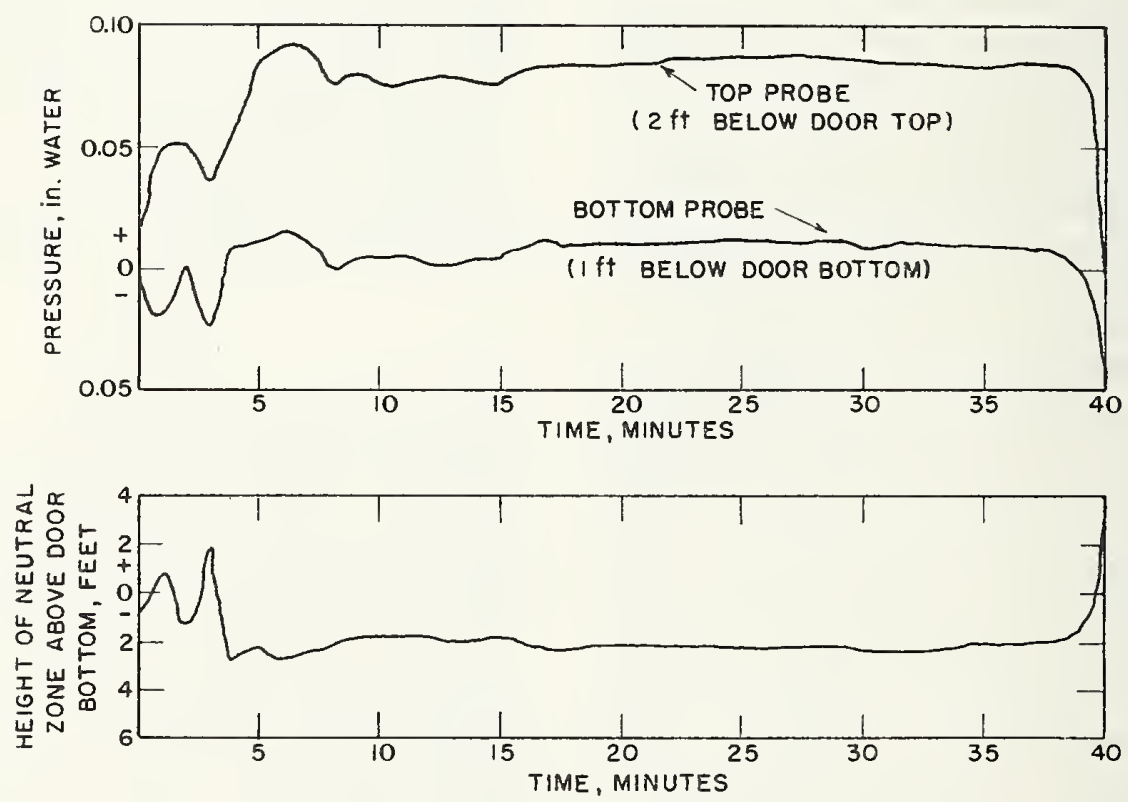

FIGURE 5. Observed pressures and location of neutral pressure zone in furnace during door test No. 3. 
fire retardant paint permitted fire breakthrough in only $11 \frac{1}{4} \mathrm{~min}$. However, significantly longer fire duration periods, ranging from 20 to $37 \frac{1}{2} \mathrm{~min}$, were obtained when fire retardant paints A (containing glass fiber reinforcement) and E (applied over woven glass fiber roving or cloth) were used. The improvement was true for doors with facings in which the panel spaces were not filled as well as for the filled panel doors.

None of the doors modified with added protective materials achieved fire duration times comparable to those obtained by the two rated metal fire doors introduced for comparison.

This study was undertaken to determine whether simple alterations to existing door assemblies could improve their fire behavior, and no consideration was given to the design of improved doors or to the use of chemical impregnation treatments which are normally applied prior to manufacture. It has been shown, however, that the fire duration period for doors impregnated with ammonium salts was not materially increased over that of untreated doors, even though the amount of flaming was significantly reduced [7, 8]. In tests conducted by the British Building Research Station [8], considerable improvement was obtained in the fire resistance of existing panel and flush doors by the application of $\frac{3}{8}$-in. thick plasterboard infilling and cladding. However, because of the differences in test procedures and failure criteria, the times are not directly comparable.

Although unexposed surface temperatures were not measured in this study, it is interesting to note, from an evaluation of small model door panel tests of similar constructions conducted as another phase of this investigation, that the order of failure by time to flame-through usually corresponded to that by time to limiting temperature rise (see fig. 6). Since nearly every test failure by flame-through occured in the vicinity of the standard thermocouple pad, it is probable that the observed good correlation with temperature-rise failure times was the result of the insulating effect of the pad in both cases. Exceptions to this correlation were noted for doors faced with noncombustible asbestos-cement board and sheet steel. Because of the superior integrity provided by the noncombustible facing, the times to flame-through were considerably longer than the times to limiting temperature rise.

Since the smoke issuing through the doors under test could not be effectively collected in the test building, a collection box was placed over the door to act as a temporary accumulator. Although the

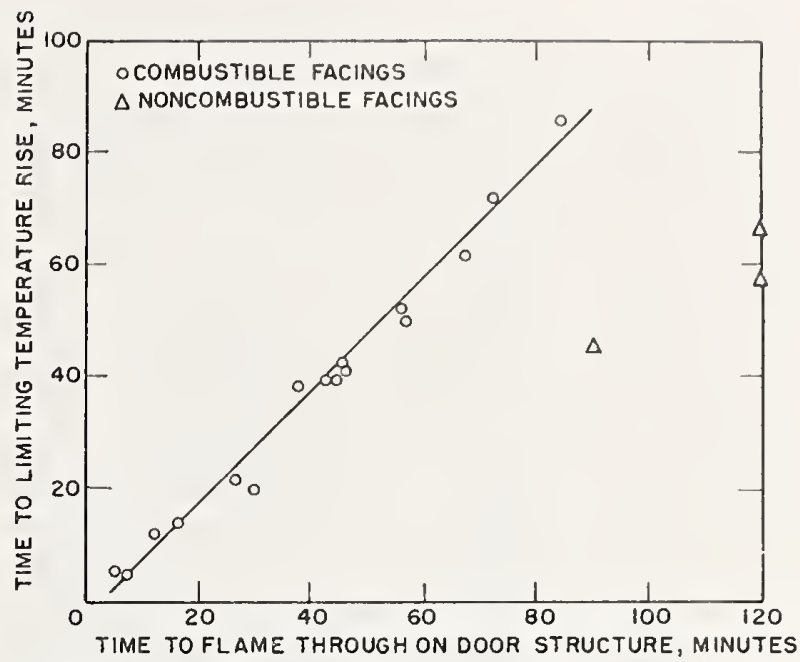

Figure 6. Model doors: failure times by temperature rise $\left(325^{\circ} \mathrm{F}\right.$, one point), and flame penetration.

extent to which this is justified has not been fully established, the comparative results in figure 4 and table 2 illustrate several significant findings. By expressing the results in terms of the time to reach a specified optical density (or smoke concentration), we are able to compare the ability of the door assembly to retard smoke passage, and thus to provide time for rescue operations. As might be expected, the doors with noncombustible facings of sheet steel and asbestos-cement board were better than comparable doors with hardboard facings by

TABLE 2. Smoke measurements

\begin{tabular}{|c|c|c|c|}
\hline \multirow{2}{*}{ Test No. } & \multicolumn{3}{|c|}{ Time, min, to reach listed optical density } \\
\hline & $0.1 / \mathrm{ft}$ & $0.2 / \mathrm{ft}$ & $0.5 / \mathrm{ft}$ \\
\hline $2 \mathrm{~A}$ & 0.2 & 0.4 & $2 . \overline{3}$ \\
\hline $2 \mathrm{~B}$ & .3 & .5 & 2.7 \\
\hline $3 A$ & 1.2 & 1.7 & 3.4 \\
\hline $3 \mathrm{~B}$ & 0.4 & 0.8 & 1.9 \\
\hline $4 \mathrm{~A}$ & 2.4 & 3.0 & 3.7 \\
\hline $4 B$ & 1.9 & 3.1 & 3.0 \\
\hline $5 \mathrm{~A}$ & 0.1 & 0.3 & 1.9 \\
\hline $5 \mathbf{B}$ & .2 & .3 & 1.0 \\
\hline $6 \mathrm{~A}$ & 1.1 & 1.3 & 1.4 \\
\hline $6 \mathbf{B}$ & 2.2 & 2.3 & 3.0 \\
\hline $7 \mathrm{~A}$ & 1.9 & 2.2 & 2.9 \\
\hline $7 \mathrm{~B}$ & N.D.* & N.D. & N.D. \\
\hline $8 \mathrm{~A}$ & 1.8 & 2.2 & $>3.7$ \\
\hline $8 B$ & 0.7 & 1.0 & 4.0 \\
\hline
\end{tabular}

*N.D. $=$ No data. 
providing 1 or $2 \mathrm{~min}$ of additional delay in the buildup to a given smoke concentration.

However, of the several methods instituted to check the transmission of smoke around the edges of the door, including cladding the door edges and the jamb and stops with sheet metal, none seemed to offer a really effective barrier. The use of metal weather strips appeared to be only slightly effective. The application of a reinforced fire-retardant paint to the door edges did not prove effective in these tests even though such a thick coating would sometimes intumesce and provide a seal between the door and its frame. Preliminary small-scale tests at NBS of a commercial intumescent strip for application to door edges or jambs indicated that the product may react more quickly than a paint coating. Using the strip, which is available in Europe for building and shipboard installations, a significant decrease was obtained in the quantity of smoke passing around the edges in a wood door and frame assembly as compared to that from an assembly not so modified, as shown in figure 7.

The intumescent strips and paint coatings did not appear to provide the full requirements of a smoke barrier for several reasons. Thermal sensitive devices would not react to the passage of relatively cool smoke which can quickly spread throughout a building from a distant fire. Even in the presence of a nearby fire, the heat necessary to initiate intumescence may not be available for some time, by which point untenable smoke conditions may already have been reached in an adjoining space. Finally, such materials applied at the edges only cannot restrict the direct transmission of smoke through a disintegrating door.

Because the production of smoke is a complex function of the chemical and physical nature of a material, of the type and severity of exposure and completeness of combustion and other properties of the environment, it is clear that additional smoke test data is vital to a better understanding of the problem. For a more thorough evaluation of the smoke producing properties of the material, it would be desirable to have a laboratory test chamber similar to one recently described [9], with provisions for varying and controlling fire exposure conditions and for reproducible quantitative measurement of the smoke produced. Also, the development of a standardized and quantitative method of measuring smoke transmission during fire tests would aid considerably in the comparative evaluation of door assemblies.

The movement of smoke (and other decomposition products) from one area to another results from a difference in pressure. In the typical fire situation, the pressure in the fire area is greater at high levels and less at low levels, than the pressure in an adjoining area or room. Thus, air flows into the fire area through low level openings, and smoke and gases flow out of the fire area through high level openings. The horizontal plane at which the pressures are equal is termed the neutral zone, and it is possible to adjust the location of the neutral zone by changing the ratio of the sizes of the openings and their relative heights.

In the NBS wall furnace during test, the neutral zone is typically below the level at which the door sill is located, so that differences in pressure exist similar to those shown in figure 3 . This represents the steady-state condition due to a combination of the elevated furnace temperature and the air supply pressure, and exists after a transient buildup period of approximately 3 or $4 \mathrm{~min}$. In order to illustrate the effects of vertical shifts in the neutral zone on

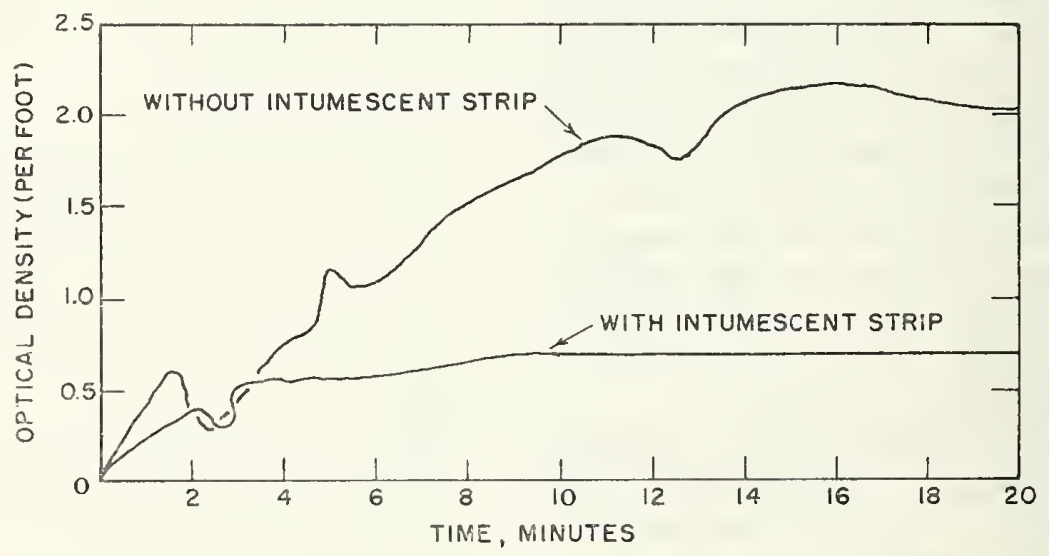

Figure 7. Efject of intumescent strip on smoke passage around unfirished wood model doors. 


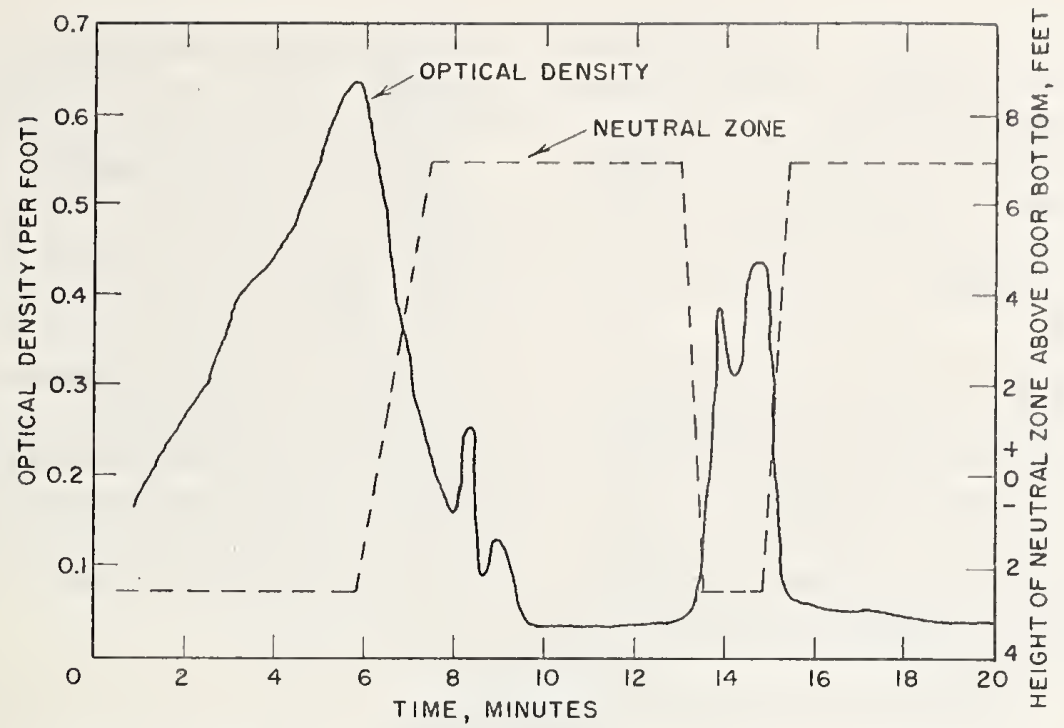

Figure 8. Effect of neutral pressure zone location on smoke passage around a class $B$ rated metal door.

Test No. 8B.

smoke passage through the door openings, the low level openings below the test frame were closed and opened several times during test No. 8 (see fig. 8). As shown, changes in the location of the neutral zone were quickly translated into changes in the smoke density, and it was possible to reduce the optical density to a very low value when the neutral zone was shifted to the top of the door or above.

In the absence of more detailed information, it is recommended that, in the standard fire test procedure, the neutral pressure zone in the furnace be located at a level not exceeding one-third the door height.

The results of this demonstration may be considered in terms of a room interconnected with a fire- and smoke-filled corridor by means of a door containing the usual separations and clearances. For such a room to remain smoke-free, it is necessary to ensure that the neutral zone is maintained above the door top. This can be effected by increasing the area of high-level corridor openings to the exterior, e.g., by venting. For the parallel problem of maintaining a corridor free of smoke when fire occurs in an adjoining room, windows in exterior walls at levels lower than the door lintel should be considered undesirable unless precautions are taken to keep them closed and intact [10]. The establishment of the required high-level openings could be arranged in colnection with an appropriate fire $\mathrm{or}^{\circ}$ smoke detection system.

Some interest is currently being shown in the generation of higher pressure conditions in occupied areas or escape routes than in the rest of a building $[10,11]$. Such pressurization schemes require the use of high capacity fans and can only be effective in relatively well-sealed enclosures.

\section{Summary}

This study dealt with possible means for improving doors as fire and smoke barriers and was directed to the particular problem of entrance doors to individual dwelling units in apartment buildings, rooming houses and hotels. Although much of the work was of a preliminary and exploratory nature, certain conclusions may be drawn from the results so far obtained.

First, it would appear that some of the test methods and test criteria require improvement or refinement. Radiation flux measurements, as a basis for classification, should be made for all doors, including those for which there is no limiting temperature now established. A standardized and quantitative measurement of smoke transmission around the edges of a door is also badly needed, unless it is to be assumed that fire doors are provided without regard to life safety. In addition, more careful standardization of furnace pressures and the location of the neutral pressure zone is necessary to ensure comparable smoke and fire penetration observations. 
Second, the tests have shown that existing doors and door frames of combustible construction may be modified to considerably enhance their fire resistance. However, the improvement will probably not raise them to the level provided by the lowest rated fire door, and the work entailed by such modifications seems unlikely to make the project economically feasible.

Third, in none of the tests was there sufficient indication of an effective means of preventing the transmission of smoke around the edges of doors, even those rated as good fire barriers. The use of intumescent materials on door and frame edges to form a seal in the event of fire, offers some possibilities, but will require the development of substances reacting at lower temperatures than do those now available. Here, too, a method of assuring the durability of the protection will have to be devised.

Finally, it may be possible, in some cases, to mitigate the effects of smoke by proper pressure balance between a room and a smoke-filled corridor. By increasing the area of high-level corridor openings to the exterior, e.g., by venting, it may be possible to maintain the neutral pressure zone above the door top and to prevent smoke penetration into the room. Other efforts can and should be directed to the basic design of buildings and the use of suitable devices to maintain escape areas fire- and smoke-free regardless of the effectiveness of doors.

\section{References}

[1] Exposure 'Tests of Ordinary Wood Doors, Underwriters' Laboratories, Ine. Bulletin of Research No. 6., Dee. 1938.

[2] F. W. Bieberdorf and C. H. Yuill, An Investigation of the Hazards of Combustion Products in Building Fires, Southwest Research Institute, San Antonio, Oet. 14, 1963.

[3] Standard for the Proteetion of Openings in Walls and Partitions Against Fire, National Fire Codes No. 80, National Fire Protection Assoeiation, 1962 Edition.

[4] Fire Tests of Door Assemblies, Underwriters' Laboratories, Inc. Standard UL 10(b), 3rd Edition, Nov. 1957.

[5] Standard Methods of Fire Tests of Door Assemblies, Ameriean Soeiety for Testing and Materials Designation E 152, 1958 .

[6] British Standard Specifieation for Fire Tests on Building Materials and Structures, B.S. 476, Part 1, British Standards Institution, London, 1953.
[7] Fire Exposure Tests of Old Fireproofed Wood Doors, Underwriters' Laboratories, Inc. Bulletin of Research No. 5, Nov. 1938.

[8] C. J. Webster and L. A. Ashton, Investigations on Building Fires, Part IV Fire Resistance of Timber Doors, National Building Studies Technical Paper No. 6, HMSO, London, 1951.

[9] A Method of Measuring Smoke Density, Quarterly of the National Fire Protection Association, Vol. 57, No. 3, January 1964.

[10] Private Communieation from J. H. MeGuire, National Research Council of Canada, Ottawa.

[11] Private Communication from H. I. Malhotra, Joint Fire Research Organization, Boreham Wood, England.

is U. S. GOVERNMENT PRINTING OFFICE: $1966-793-770$ 


\section{ANNOUNCEMENT OF NEW PUBLICATIONS IN BUILDING SCIENCE SERIES}

Superintendent of Documents, Government Printing Office, Washington, D.C., 20402

Dear Sir:

Please add my name to the announcement list of new publications to be issued in the series: National Bureau of Standards Building Science Series.

Name

Company

Address

City

State

Zip Code

(Notification key $\mathrm{N}-339$ ) 





\section{THE NATIONAL BUREAU OF STANDARDS}

The National Bureau of Standards is a principal focal point in the Federal Government for assuring maximum application of the physical and engineering sciences to the advancement of technology in industry and commerce. Its responsibilities include development and maintenance of the national standards of measurement, and the provisions of means for making measurements consistent with those standards; determination of physical constants and properties of materials; development of methods for testing materials, mechanisms, and structures, and making such tests as may be necessary, particularly for government agencies; cooperation in the establishment of standard practices for incorporation in codes and specifications; advisory service to government agencies on scientific and technical problems; invention and development of devices to serve special need of the Government; assistance to industry, business, and consumers in the development and acceptance of commercial standards and simplified trade practice recommendations; administration of programs in cooperation with United States business groups and standards organizations for the development of international standards of practice; and maintenance of a clearinghouse for the collection and dissemination of scientific, technical, and engineering information. The scope of the Bureau's activities is suggested in the following listing of its three Institutes and their organizational units.

Institute for Basic Standards. Applied Mathematics. Electricity. Metrology. Mechanics. Heat. Atomic Physics. Physical Chemistry. Laboratory Astrophysics.* Radiation Physics. Radio Standards Laboratory:* Radio Standards Physics; Radio Standards Engineering. Office of Standard Reference Data.

Institute for Materials Research. Analytical Chemistry. Polymers. Metallurgy. Inorganic Materials. Reactor Radiations. Cryogenics.* Materials Evaluation Laboratory. Office of Standard Reference Materials.

Institute for Applied Technology. Building Research. Information Technology. Performance Test Development Electronic Instrumentation. Textile and Apparel Technology Center. Technical Analysis. Office of Weights and Measures. Office of Engineering Standards. Office of Invention and Innovation. Office of Technical Resources. Clearinghouse for Federal Scientific and Technical Information.**

*Located at Boulder, Colorado, 80301.

**Located at 5285 Port Royal, Springfield, Virginia, 22171. 
U.S. DEPARTMENT OF COMMERCE

WASHINGTON, D.C. 20230
POSTAGE AND FEES PAID U.S. DEPARTMENT OF COMMERCE

OFFICIAL BUSINESS 